\title{
Arthropods Biodiversity in Agricultural Landscapes: Effects of Land Use and Anthropization
}

\author{
Enrico Previati, Elisa Anna Fano, Marilena Leis* \\ Dipartimento di Biologia ed Evoluzione, Università di Ferrara \\ Via Luigi Borsari 46, 44100 Ferrara, Italy
}

Received: 2 December 2006. Accepted: 2 January 2007

\begin{abstract}
The greatest proportion of Po river plain is occupied by arable lands. Negative effects of modern intensive agriculture on biodiversity can derive from various phenomena operating at different spatial scales, from local to regional ones. If agricultural fields are subjected to periodical disturbances by farming practices, also landscape structure can influence community structure in the fields providing refugial areas or alternative trophic resources. In the same way in perennial habitats, such as strips and meadows, community structure and composition may be linked to both local factors and surrounding land use, that can influence organism persistence and dispersal mechanisms. We studied some natural and anthropized habitats in a wide agricultural area in the province of Ferrara (conventional annual and perennial fields, herbaceous strips, hedgerows and meadows) to investigate relationships between arthropod community structure and both local impact factors (habitat type, management) and surronding landscape structure and use. Results from uni and multivariate analysis showed a great influence on trophic and taxonomic structure of habitat type and quality. A less complex landscape had only slightly influence on trophic structure, leading to higher abundance and richness of generalist taxa. In conclusion we emphasize the importance of maintaining high-quality habitats to enhance arthopod diversity in agricultural landscapes.
\end{abstract}

Key-words: agriculture, arthropods, community structure, habitat type, landscape complexity.

\section{Introduction}

Biodiversity in agricultural areas may have been influenced by changes deriving from agricultural intensification on various spatial scales ranging from local to regional ones (Clough et al., 2005). At the field scale, the introduction of pesticides and the shift from organic to synthetic fertilizers have had a negative impact on fauna and flora (Matson et al., 1997) and has resulted in greatly simplified agroecosystems (Swift et al., 1996). At the same time, at the landscape scale, agricultural specialization has led to rural simplified landscapes dominated by arable crops where natural habitats are reduced to small remnants with a patchy distribution across the fields in varying densities and connectivity levels (Saunders et al., 1994). As pointed out by scientists, land use changes are among the most immediate drivers of species diversity at both local and landscape scale (van der Putten et al., 2000). One of the possible ways of counteract- ing the loss of biodiversity in moderne agricultural landscapes might be to reduce land use intensity. The general concern about this problem has been finding political resonance leading to management efforts promoting or enhancing more recent habitats that are less disturbed than cultivated areas, such as set-asides or field boundaries.

At the community level, invertebrates are more sensitive to habitat changes than plants and vertebrates (Burel et al., 1998). In general, species diversity and community patterns of terrestrial arthropod has been found to be positively associated with habitat complexity (Lassau and Hochuli, 2005). Arable fields are subject to periodical disturbances such as ploughing, harrowing or pesticide applications, and are often left bare in wintertime. Reduction of faunistic diversity is one of the main effects of these practices (Benton et al., 2003). Organic farming or reduction in mechanical tillage can favour in- 
creases in arthropod abundance and diversity (Feber et al., 1998; Schmidt et al., 2005) and soil biomass (Kladivko, 2001). Perennial habitats such as field boundaries, hedgerows or grasslands, with a habitat structure of higher quality, can host more complex communities (Hinsley and Bellamy, 2000). Also some management operations, for example mowing, have a direct effect on insects by damaging or killing individuals or removing them from the sites (Di Giulio et al., 2001).

It is increasingly recognized that not only local factors but also spatial surroundings of habitat patches may have strong influence on local diversity and abundance of organisms (Jeanneret et al., 2003; Holland et al., 2004). Habitat variability and heterogeneity in the surrounding landscape can increase landscape complexity and can affect biodiversity in a local site (Duelli, 1997). Undisturbed landscape elements may act as refuges for several arthropods, providing alternative prey, hosts or nectar (Pfiffner and Wyss, 2004) and provide sources for recolonising arable fields or other perennial habitats (Schmidt and Tscharnke, 2005).

We studied arthropod communities in an agricultural landscape of Po plain at a two level spatial scale: we compared six habitat types, from highly anthropized to more natural ones, in the two contrasting situations of presence or absence of natural habitats in the surrounding landscape. Our aim was to understand the different role and the importance of local habitat and landscape variability in influencing taxonomic and trophic community structure and composition.

\section{Materials and methods}

\subsection{Study area and sampling sites}

The experimental activity interested an area, called Mezzano, located in the province of Ferrara, Northern Italy. This territory, reclaimed during the ' 70 s, is interested by intensive agricultural activities and the main cultivations are annual seed and horticultural or pluriannual fodder crops. Study area can be considered homogeneous for origin and time since conversion to agriculture, so we can exclude large-scale regional or historical factors (such as meteorological or geographical events, large-scale land- scape diversity, land-use or anthropic effects) that can interact with local environmental factors (Clough et al., 2005).

Agricultural fields in the area range in size about 20 ha. Natural or semi-natural perennial habitats are rare and do not exceed $4 \%$ of total area, and about $80 \%$ of arable land has bare round cover in winter (Minarelli, 2004). Natural vegetation is confined in few grassland patches ranging until 30-40 ha and in linear structures, ranging from 8 to $20 \mathrm{~m}$ width, with herbs (field and canal boundaries and strips), shrubs and trees (hedgerows).

We selected twelve sites belonging to six habitat types along a gradient of increasing wildness (more detailed information are in Tab. 1) and decreasing anthropization: conventional fields with annual crops (hosting alternatively cereals and vegetables), conventional fields with perennial crops (alfalfa), herbaceous strips, hedgerows, mowed and non mowed meadows. Land use was mapped from a field survey in a radius of $500 \mathrm{~m}$ around each site and digitalized to a GIS map. This radius is reasonably large enough to describe the landscape relevant to dispersal of most arthropods (Schmidt and Tscharntke, 2005). We defined two categories of landscape complexity, depending on the presence or absence of natural habitats in the mapped area with a proportion higher than $5 \%$. For each habitat type we could have two sites, respectively with high (HC) and low (LC) landscape complexity.

\subsection{Arthropod sampling}

Arthropods were sampled by three pitfall traps (diameter $10 \mathrm{~cm})$ in the centre $(20 \mathrm{~m}$ far from margin for fields and meadows, obviously less for strips and hedgerows) of each site and opened for 2-week sampling periods each month in May, July and August 2004. Traps were filled with ethylene glycol as preservative. Arthropods were determined to family level and classified into one of the five trophic groups: phytophagous, predators, parasitoids, polyphagous and detritivores, depending on the predominant feeding habit of species belonging to a given taxonomic unit (Koricheva et al., 2000).

\subsection{Data Analysis and Statistics}

Taxa richness ( $S$, number of taxa), total activity density $\left(N=\left[n^{\circ}\right.\right.$ individuals $/($ trap $*$ days $\left.)\right] * 10$; 
Table 1. Description of sampling sites.

\begin{tabular}{|c|c|c|c|c|c|c|}
\hline \multirow[t]{2}{*}{$\begin{array}{l}\text { Site } \\
\text { code }\end{array}$} & \multirow[t]{2}{*}{ Habitat type } & \multicolumn{2}{|c|}{$\begin{array}{l}\text { Location: } \\
\text { coordinates }\end{array}$} & \multirow[t]{2}{*}{$\begin{array}{l}\text { Crop/ } \\
\text { Vegetation }\end{array}$} & \multirow[t]{2}{*}{ Management } & \multirow[t]{2}{*}{ Surrounding Land use } \\
\hline & & $\mathrm{N}$ & $\mathrm{E}$ & & & \\
\hline $\mathrm{CA}_{1}$ & Annual crop & $44^{\circ} 40^{\prime}$ & $11^{\circ} 56^{\prime}$ & Ryegrass & Conventional & LC: arable land \\
\hline $\mathrm{CA}_{2}$ & Annual crop & $44^{\circ} 40^{\prime}$ & $12^{\circ} 02^{\prime}$ & Maize & Conventional & HC: arable land, meadows \\
\hline $\mathrm{CP}_{1}^{2}$ & Perennial crop & $44^{\circ} 40^{\prime}$ & $12^{\circ} 04^{\prime}$ & Alfalfa & $\begin{array}{l}\text { Conventional } \\
3-4 \text { cuts/year }\end{array}$ & LC: arable lands \\
\hline $\mathrm{CP}_{2}$ & Perennial crop & $44^{\circ} 41^{\prime}$ & $12^{\circ} 05^{\prime}$ & Alfalfa & $\begin{array}{l}\text { Conventional } \\
3-4 \text { cuts/years }\end{array}$ & $\begin{array}{l}\text { HC: arable lands, meadows, } \\
\text { grass strips, hedgerows }\end{array}$ \\
\hline $\mathrm{F}_{1}$ & Grass strip & $44^{\circ} 38^{\prime}$ & $12^{\circ} 03^{\prime}$ & Wild grasses & 3-4 cuts/years & LC: arable lands \\
\hline $\mathrm{F}_{2}$ & Grass strip & $44^{\circ} 44^{\prime}$ & $11^{\circ} 58^{\prime}$ & Wild grasses & 3-4 cuts/years & $\begin{array}{l}\text { HC: arable lands, meadows, } \\
\text { grass strips, hedgerows }\end{array}$ \\
\hline $\mathrm{S}_{1}$ & Hedgerow with grass strip & $44^{\circ} 41^{\prime}$ & $12^{\circ} 01^{\prime}$ & $\begin{array}{l}\text { Shrubs, trees, } \\
\text { wild grasses }\end{array}$ & 3-4 cuts/years & LC: arable lands \\
\hline $\mathrm{S}_{2}$ & Hedgerow with grass strip & $44^{\circ} 44^{\prime}$ & $11^{\circ} 58^{\prime}$ & $\begin{array}{l}\text { Shrubs, trees, } \\
\text { wild grasses }\end{array}$ & 3-4 cuts/years & $\begin{array}{l}\text { HC: arable lands, meadows, } \\
\text { grass strips, hedgerows }\end{array}$ \\
\hline $\mathrm{Psf}_{1}$ & Meadow & $44^{\circ} 40^{\prime}$ & $12^{\circ} 02^{\prime}$ & Wild grasses & $1-2$ cuts/years & LC: arable lands \\
\hline $\mathrm{Psf}_{2}$ & Meadow & $44^{\circ} 40^{\prime}$ & $12^{\circ} 00^{\prime}$ & Wild grasses & $1-2$ cuts/years & $\begin{array}{l}\text { HC: arable lands, meadows, } \\
\text { grass strips }\end{array}$ \\
\hline $\mathrm{P}_{1}$ & Grassland & $44^{\circ} 40^{\prime}$ & $11^{\circ} 55^{\prime}$ & Wild grasses & No cuts & LC: arable lands \\
\hline $\mathrm{P}_{2}$ & Grassland & $44^{\circ} 38^{\prime}$ & $12^{\circ} 06^{\prime}$ & Wild grasses & No cuts & $\begin{array}{l}\text { HC: arable lands, meadows, } \\
\text { grass strips }\end{array}$ \\
\hline
\end{tabular}

Brandmayr et al., 2005), Shannon diversity ( $H^{\prime}$ $=-\sum\left[p_{i} \cdot \ln p_{i}\right]$, where $p_{i}$ is the proportion between the number of individuals of the species $i$ and the total number of individuals; Magurran, 1988), richness and activity density of trophic groups were tested for the effects of habitat type and landscape complexity using a two ways ANOVA model (habitat effect with six levels and landscape complexity effect with two levels). Data were fourth root transformed when necessary to achieve normality. Comparisons where performed using a post-hoc Tukey test.

Similarity patterns in community structure, trophic structure and arthropod families assemblages were explored using non metric multidimensional scaling (NMDS) ordination for the index, trophic group richness and activity density indicator and family assemblage data separately (McCune and Mefford, 1997). As distance measure we used euclidean distance for the first

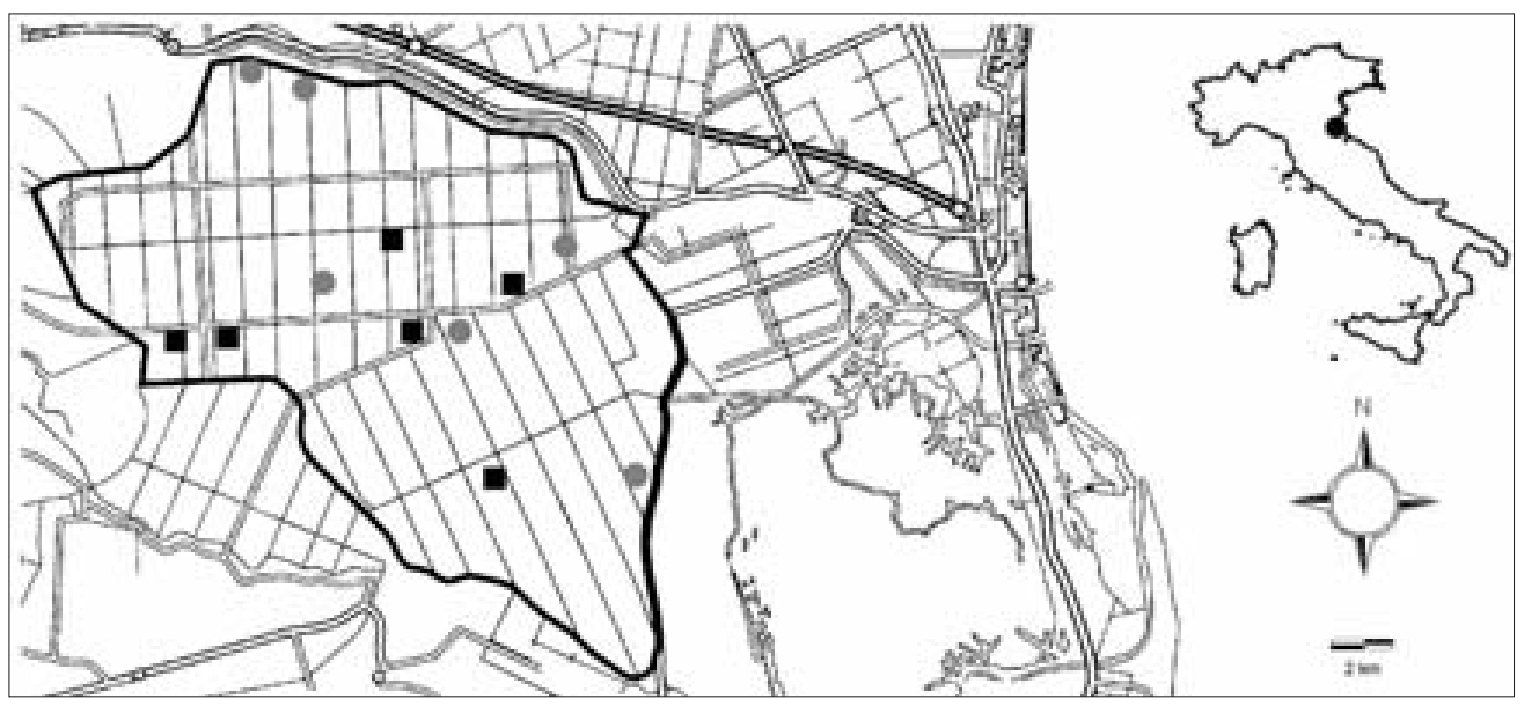

Figure 1. Map of the study area and location of the sampling sites. Black squares indicate sites with low complexity surrounding landscape, grey circles indicate sites with high complexity surrounding landscape. 
Table 2. Results of two way ANOVA (Factor habitat type). For each habitat type, means and standard deviations are reported. Values with the same letter are not significantly different.

\begin{tabular}{|c|c|c|c|c|c|c|c|c|c|c|c|c|c|c|}
\hline & \multicolumn{14}{|c|}{ Habitat type } \\
\hline & \multicolumn{2}{|c|}{ Dependent variable $\mathrm{P}$} & \multicolumn{2}{|c|}{$\mathrm{CA}$} & \multicolumn{2}{|c|}{$\mathrm{CP}$} & \multicolumn{2}{|l|}{$\mathrm{F}$} & \multicolumn{2}{|c|}{ S } & \multicolumn{2}{|c|}{ Psf } & \multicolumn{2}{|c|}{$\mathrm{P}$} \\
\hline \multirow{13}{*}{ 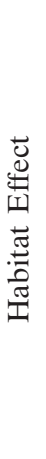 } & $\mathrm{S}$ & $<0.001$ & $4.17^{\mathrm{a}}$ & 0.32 & $4.67^{\mathrm{a}}$ & 0.67 & $7.87^{\mathrm{b}}$ & 0.68 & $7.39^{\mathrm{b}}$ & 0.73 & $16.11^{\mathrm{c}}$ & 1.04 & $13.06^{\mathrm{c}}$ & 0.73 \\
\hline & $\mathrm{N}$ & $<0.001$ & $22.43^{\mathrm{a}}$ & 3.86 & $20.00^{\mathrm{ab}}$ & 3.83 & $33.95^{\mathrm{ab}}$ & 4.51 & $40.54^{\mathrm{b}}$ & 4.95 & $71.95^{\mathrm{bc}}$ & 7.38 & $45.05^{\mathrm{bc}}$ & 4.83 \\
\hline & H' & $<0.001$ & $1.04^{\mathrm{a}}$ & 0.08 & $1.25^{\mathrm{a}}$ & 0.11 & $1.68^{\mathrm{b}}$ & 0.10 & $1.36^{\mathrm{b}}$ & 0.10 & $2.00^{c}$ & 0.06 & $1.77^{\mathrm{bc}}$ & 0.05 \\
\hline & N Phytophagous & 0.0417 & $6.67^{\mathrm{a}}$ & 1.90 & 6.55 & 1.66 & 6.67 & 1.14 & 7.38 & 1.90 & $12.01^{\mathrm{b}}$ & 2.15 & 5.30 & 0.96 \\
\hline & S Phytophagous & $<0.001$ & $1.33^{\mathrm{a}}$ & 0.17 & $1.58^{\mathrm{ab}}$ & 0.38 & $2.52^{\mathrm{bd}}$ & 0.28 & $2.26^{\mathrm{bd}}$ & 0.39 & $5.72^{c}$ & 0.57 & $3.61^{\mathrm{d}}$ & 0.44 \\
\hline & N Parasitoids & $<0.001$ & $0^{\mathrm{a}}$ & 0 & $0.24^{\mathrm{a}}$ & 0.24 & $0.63^{\mathrm{a}}$ & 0.29 & $0.66^{\mathrm{a}}$ & 0.29 & $3.86^{\mathrm{b}}$ & 1.08 & $0.63^{\mathrm{a}}$ & 0.24 \\
\hline & S Parasitoids & $<0.001$ & $0^{\mathrm{a}}$ & 0 & $0.08^{\mathrm{a}}$ & 0.08 & $0.22^{\mathrm{a}}$ & 0.09 & $0.35^{\mathrm{ab}}$ & 0.12 & $1.44^{\mathrm{c}}$ & 0.25 & $0.89^{c}$ & 0.23 \\
\hline & N Polyphagous & 0.0094 & 1.71 & 0.40 & $3.21^{\mathrm{a}}$ & 0.97 & 2.69 & 0.73 & $1.35^{\mathrm{b}}$ & 0.64 & $9.00^{\mathrm{a}}$ & 2.45 & 3.45 & 1.10 \\
\hline & S Polyphagous & 0.0105 & $0.57^{\mathrm{a}}$ & 0.11 & 0.92 & 0.19 & 0.83 & 0.14 & $0.39^{\mathrm{a}}$ & 0.12 & $1.22^{\mathrm{b}}$ & 0.15 & 0.78 & 0.17 \\
\hline & N Predators & $<0.001$ & $9.48^{\mathrm{a}}$ & 1.53 & $8.57^{\mathrm{ad}}$ & 2.20 & $19.00^{\text {bd }}$ & 3.32 & $22.68^{\mathrm{b}}$ & 3.32 & $34.04^{\mathrm{c}}$ & 3.35 & $26.35^{\mathrm{b}}$ & 2.48 \\
\hline & S Predators & $<0.001$ & $1.80^{\mathrm{a}}$ & 0.17 & $1.50^{\mathrm{a}}$ & 0.23 & $2.91^{\mathrm{b}}$ & 0.33 & $3.00^{\mathrm{b}}$ & 0.15 & $3.83^{\mathrm{c}}$ & 0.20 & $4.28^{c}$ & 0.27 \\
\hline & N Detritivores & $<0.001$ & $2.95^{\mathrm{a}}$ & 2.19 & $1.43^{\mathrm{ad}}$ & 0.73 & $4.84^{\mathrm{bd}}$ & 1.29 & $8.42^{\text {bd }}$ & 3.61 & $13.04^{\mathrm{c}}$ & 2.45 & $9.19^{c}$ & 1.52 \\
\hline & S Detritivores & $<0.001$ & $0.37^{\mathrm{a}}$ & 0.12 & $0.58^{\mathrm{ad}}$ & 0.29 & $1.30^{\mathrm{ad}}$ & 0.22 & $1.35^{\text {bd }}$ & 0.28 & $3.89^{c}$ & 0.42 & $3.33^{\mathrm{c}}$ & 0.49 \\
\hline
\end{tabular}

and second data set while we used Bray-Curtis similarities for family assemblage data set. Only families contributing to $99 \%$ of total activity density were included and data were $\log (\mathrm{x}+1)$ transformed.

\section{Results}

A total of 4733 arthropods from 98 families were sampled and identified. Coleoptera (Families Carabidae and Staphylinidae) and Araneae were the most abundant orders. Highest family richness was in order Coleoptera (22 families), Heteroptera and Hymenoptera (14 families each one). On average 38.16 individuals and 8.52 families per trap were caught in one site (ranging from 7 to 81 individuals and from 4 to 18 families in $\mathrm{CA}_{1}$ and $\mathrm{Psf}_{1}$ respectively).

Habitat type was the main factor influencing both taxonomic and trophic community structure (Tab. 2). Family richness and Shannon diversity were significantly lower in both field types than other habitats and also in hedgerows and strips than in meadows. A similar pattern was found for all trophic groups family richness and also predator activity density. In some cases there were no significant differences between perennial alfalfa fields and strips or hedgerows. Total activity density was less variable: it was significantly higher in mowed meadows than fields, strips and hedgerows and higher in hedgerows and non mowed meadows then cereal fields. Activity density of other trophic groups showed only rare significant differences between habitat types. Polyphagous taxa were similar among all sites for both richness and activity density. Only in mowed meadows they had higher values than fields and linear habitats. In general we did not find differences between the two field types (cereals and alfalfa), and between the two linear habitats (strips and hedgerows). We did not find differences between mowed and non mowed meadows, even if values tended to be higher in mowed ones. Landscape complexity influenced only slightly community structure parameters: only polyphagous richness and activity density were significantly higher in less complex landscapes (Tab. 3).

NMDS analysis for both community indexes

Table 3. Results of two way ANOVA (Factor Landscape Complexity). For each habitat type, means and standard deviations are reported. Values with the same letter are not significantly different.

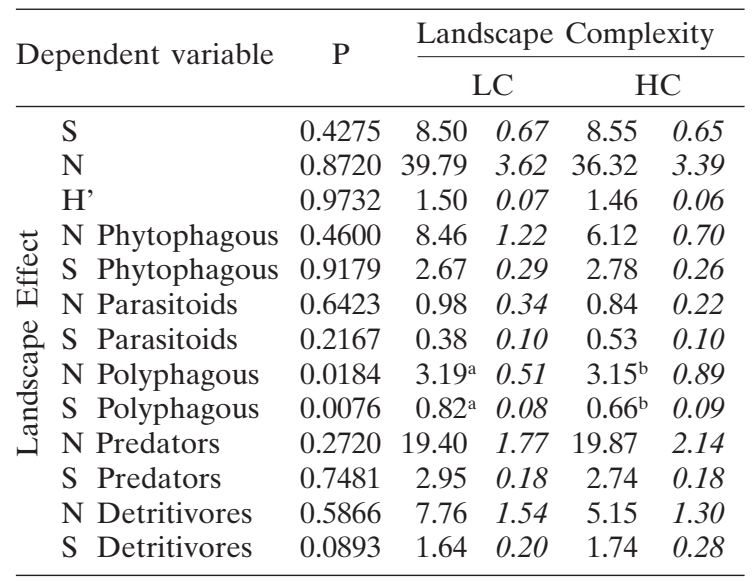



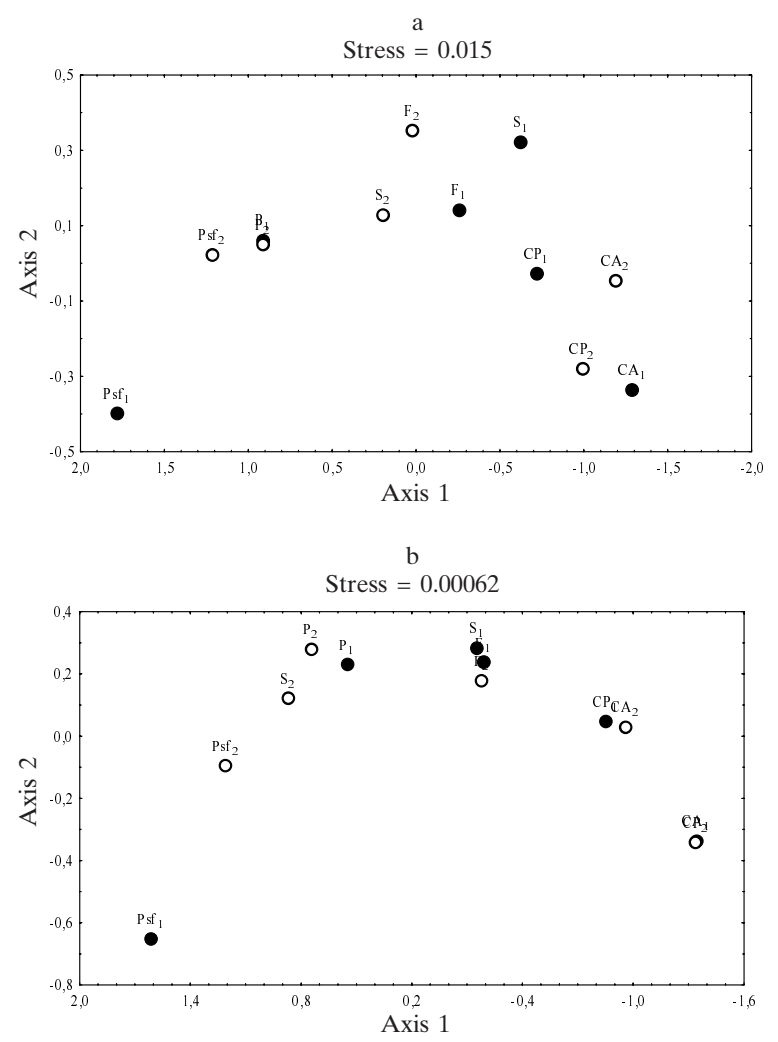

Figure 2. MDS ordination of study sites, based on community indexes (a) and trophic groups (b). Full circles indicate sites in low complexity landscape.

(Fig. 2a) and trophic groups (Fig. 2b) showed a very good ordination of sites along a gradient of increasing anthropization of habitat types, substantially independent from landscape structure.

Also ordination of arthropod assemblage

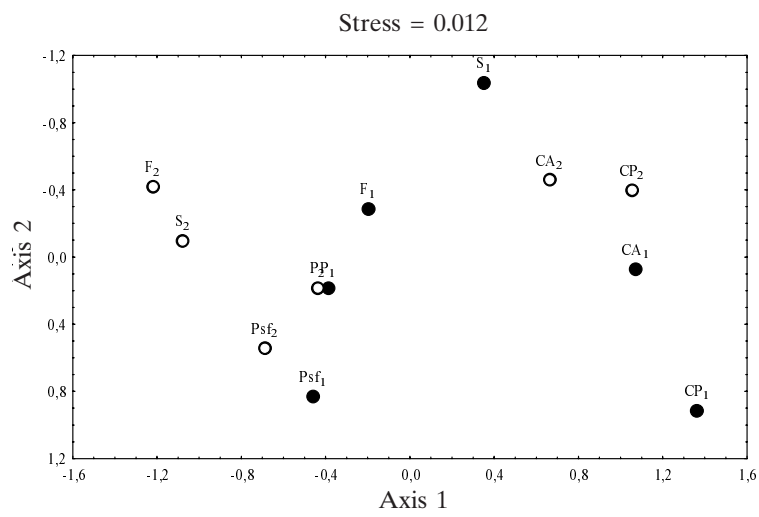

Figure 3. MDS ordination of study sites, based on the community composition of study sites. Full circles indicate sites in low complexity landscape. showed a distribution along the same gradient, separating natural and semi-natural habitats from fields, with the exception of $S_{1}$ grouping with agricultural sites (Fig. 3). For agricultural fields, strips and hedgerows, high landscape complexity sites were closest each other than low complexity ones.

\section{Discussion}

Our results are consistent with a large number of researches on habitat and landscape context. In a review (Mazerolle and Villard, 1999) the authors examined published research on species abundance and richness in different landscapes, as influenced by both local (inside patch) and landscape (patch surrounding areas) characteristics. They showed that, for the most invertebrate studies, patch characteristics explain a greater proportion of the variation in abundance and richness than what landscape characteristics usually do, and that landscape-scale variables only rarely are the only significant predictors of species presence and abundance. Such results, suggesting that landscape influence is complementary to that of habitat, are consistent with our findings. These suggest that the influence of habitat type on arthropod communities significantly depends on habitat quality. Both habitat type and quality are categories representing a sum of characteristics of sites like abiotic factors, vegetation structure, management and anthropic pressure. Several studies have shown that habitat structure and complexity may broadly affect the diversity and composition of a variety of fauna in terrestrial systems (Hansky and Singer, 2001; Hunter, 2002; Perner and Malt, 2003). This is consistent with highest activity density and richness in low disturbance perennial habitat (meadows) and lowest values in high disturbance habitat like conventional fields with bare ground cover for some months each year. Presence of natural vegetation, its structure (architecture), weed cover and diversity are factors leading to higher arthropod biodiversity providing more niches for prey (Strong et al., 1984) because of prey items associated with non-crop plants (Marshall et al., 2003). Besides that, higher plant species richness associated to perennial habitat represents more host and feeding plants in time and space influencing arthropod communities (Sparks and Parish, 1995): arthropods can be closely associated with 
particular plant species and so can reach their greatest diversity in species-rich highly structured meadows (Di Giulio et al., 2001).

Hedgerows and perennial herbaceous strips confirm their recognized role in maintaining biodiversity in agro-ecosystems (Millan de la Pena et al., 2003). We found that community composition in hedgerow $\mathrm{S}_{1}$ (in low complexity landscape) was more similar to conventional fields while $\mathrm{S}_{2}$ (high complexity landscape) grouped with perennial habitat sites. This is quite typical of edge areas, showing characteristics that highly depend on adjacent habitats and it is also consistent with previous studies (Fournier and Loreau, 2001) showing that differences in species composition between hedgerows and other habitats in agricultural landscapes can be weaker than differences in abundance and richness.

As mentioned before, landscape structure only slightly influenced arthropod communities. Landscape complexity (presence-absence of perennial natural habitats in the agricultural matrix) had significant effects only on trophic structure. The strong link between polyphagous taxa and low complexity landscape is consistent with other studies (Schweiger et al., 2005). The association of omnivorous taxa with high level of conventional crop area was most probably the result of their larger trophic niche breadth and hence greater resilience to frequent reduction in food supply as a result of agricultural management. The lack of relationships between polyphagous and habitat type is consistent with the assumption that generalist species are less infeoded to a particular habitat and therefore the habitat type has less influence on them (Jeanneret et al., 2003). Such species, not strictly dependent on trophic resource or on a suitable habitat, may invest more in dispersal (Kinnunen et al., 1996), so landscape effect on them can be stronger than on more specialist taxa.

\section{Conclusion}

This research contributes to the growing body of knowledge of the effects of local habitat characteristics and landscape context as resulting from conversion to intensive agriculture on arthropod communities. Habitat type and quality are the key determinants of arthropod abundance and diversity and community composi- tion. Since landscape structure appears to act complementarily to habitat structure, it seems important to approach environmental control models including both components as explanatory variables. Decreasing spatial or stress factors of land use intensity seems to facilitate more complex food webs and thus favour also natural pest regulation. Our findings emphasize the importance of maintaining high-quality habitats to ultimately contribute to the long term persistence of arthropod biodiversity in agricultural landscapes.

\section{Acknowledgements}

Authors wish to thank M. Brucoli, L. Lanzoni and E. Robustini for assistance in arthropod collecting and identification, G. Benini for his assistance in field work and S. Mantovani for helpful comments on the manuscript.

\section{References}

Benton T.G., Vickery J.A., Wilson J.D. 2003. Farmland biodiversity: is habitat heterogeneity the key? Trends in Ecology and Evolution, 18:182-188.

Brandmayr P., Zetto T. Pizzolotto R. 2005. I Coleotteri Carabidi per la valutazione ambientale e la conservazione della biodiversità. APAT, Manuali e Linee Guida, Roma.

Burel F., Baudry J., Butet A., Clergeau P., Delettre Y., Le Coeur D., Dubs F., Morvan N., Paillat G., Petit S., Thenail C., Lefeuvre J.C. 1998. Comparative biodiversity along a gradient of agricultural landscapes. Acta Oecologica, 19:47-60.

Clough Y., Kruess A., Kleijn D., Tscharntke T. 2005. Spider diversity in cerreal fields: comparing factors at local, landscape and regional scales. Journal of Biogeograph, 32:2007-2014.

Di Giulio M., Edwards P.J., Meister E. 2001. Enhancing insect diversity in agricultural grasslands: the roles of management and landscape structure. Journal of Applied Ecology, 38:310-319.

Duelli P. 1997. Biodiversity evaluation in agricoltural landscaspes: an approach at two different scales. Agricolture, Ecosystems and Environment, 62:81-91.

Feber R.E., Bell J., Johnson P.J., Firbank L.G., Macdonald D.W. 1998. The effects of organic farming on surface-active spider (Araneae) assemblages in wheat in southern England, UK. The Journal of Aracnology, 26:190-202.

Fournier E., Loreau M. 2001. Respective roles of recent hedges and forest patch remnants in the maintenance of ground-beetle (Coleoptera: Carabidae) diversity in an agricultural landscape. Landscape Ecology, 16:17-32.

Hanski I., Singer M.C. 2001. Extinction-colonization dy- 
namics and host-plant choice in butterfly metapopulations. American Naturalist, 158:341-353.

Hinsley S.A., Bellamy P.E. 2000. The influence of hedge structure, management and landscape context on the value of hedgerows to birds: a review. Journal of Environmental Management, 60:33-49.

Holland J.D., Bert D.G., Fahrig L. 2004. Determining the spatial scale of species' response to habitat. Bioscience, 54:227-233.

Hunter M. 2002. Landscape structure, habitat fragmentation, and the ecology of insects. Agricultural and Forest Entomology, 4:159-166.

Jeanneret P., Schupbach B., Pfiffner, L., Walter T. 2003. Arthropod reaction to landscape and habitat features in agricultural landscapes. Landscape Ecology, 18:253-263.

Kinnunen H., Jarvelainen K., Pakkala T., Tiainen J. 1996. The effect of isolation on the occurrence of farmland carabids in a fragmented landscape. Annales Zoologi Fennici, 33:165-171.

Kladivko E. 2001. Tillage systems and soil ecology. Soil \& Tillage Research, 61:61-76.

Koricheva J., Mulder C.P.H., Schmid B., Joshi J., Huss Dannell K. 2000. Numerical response of different trophic groups of invertebrates to manipulations of plant diversity in grasslands. Oecologia, 125:271-282.

Lassau S.A., Hochuli D.F. 2005. Wasp community response to habitat complexity in Sydney sandstone forests. Austral Ecology, 30:179-187.

Magurran A.E. 1988. Ecological diversity and its measurement. Princeton University Press, Princeton, New Jersey, US.

Marshall E.J.P., Brown V.K., Boatman N.D., Lutmans P.J.W., Squire G.R., Ward L.K. 2003. The role of weeds in supproting biological diversity within crop fields. Weed Research, 43:77-89.

Matson P.A., Parton W.J., Power A.G., Swift M.J. 1997. Agricultural intensification and ecosystem properties. Science, 277:504-509.

Mazerolle M.J., Villard M. 1999. Patch characteristics and landscape context as predictors of species presence and abundance: A review. Ecoscience, 6:117-124.

McCune B., Mefford M.J. 1997. PC-ORD. Multivariate Analysis of Ecological Data, Version 3.0. MjM Software Design, Gleneden Beach, OR.

Millan de la Pena N., Butet A., Delettre Y., Morant P., Burel F. 2003. Landscape context and carabid beetles (Coleoptera: Carabidae) communities of hedgerows in western France. Agriculture, Ecosystems and Environment, 94:59-72.

Minarelli G. 2004. Lineamenti agronomici. In: Nardini D., Mantovani E., Rossi R. (eds.): Studi ambientali sul Mezzano per un nuovo piano di gestione, 13-40, Minerva Edizioni, Bologna.

Perner J., Malt S. 2003. Assessment of changing agricultural land use: response of vegetation, grounddwelling spiders and beetles to the conversion of arable land into grassland. Agricolture, Ecosystems and Environment, 98:169-181.

Pfiffner L., Wyss E. 2004. Sown wildflower strips to enhance natural enemies of agricultural pests in annual and perennial cropping systems. In: Gurr G.M., Wratten S.D., Altieri M.A. (eds.): Ecolgical engineering for pest management: advances in habitat manipulation for arthropods, 165-186. CSIRO Press, Collingwood.

Saunders D.A., Hobbs R.J., Arnold G.W. 1994. The Kellerberrin project on fragmented landscapes: a review of current information. Biological Conservation, 64:185-192.

Schmidt M.H., Tscharntke T. 2005. The role of perennial habitats for Central European farmland spiders. Agriculture, Ecosystems and Environment, 105:235242.

Schmidt M.H., Roschewitz I., Thies C., Tscharntke T. 2005. Differential effects of landscape and management on diversity and density of ground dwelling farmalnd spiders. Journal of Applied Ecology, 42:281287.

Schweiger O., Maelfait J.P., Van Wingerden W., Hendrickx F., Billeter R., Speelmans M., Augenstein I., Aukema B., Aviron S., Bailey D., Bukacek R., Burel F., Diekotter T., Dirksen J., Frenzel M., Herzog F., Liira J., Roubalova M., Bugter R. 2005. Quantifying the impact of environmental factors on arthropod communities in agricultural lasndascapes across organizational and spatial scales. Journal of Applied Ecology, 42:1129-1139.

Sparks T.H., Parish T. 1995. Factors affecting the abundance of butterflies in field boundaries in Swavesey fens, Cambridgeshire, UK. Biological Conservation, 73:221-227.

Strong D.R., Lawton J.H., Southwood R. 1984. Insects on plants. Blackwell Scientific Publications, Oxford, UK.

Swift M.J., Vandermeer J., Ramakrishnan P.S., Anderson J.M., Ong C.K., Hawkins B.A. 1996. Biodiversity and agroecosystem function. In: Mooney H.A., Cushman J.H., Medina E., Sala O.E., Schulze E.D. (eds.): Functional roles of biodiversity: a global perspective, 261297. Wiley, New York.

Van der Putten W.H., Mortimer S.R., Hedlund K., Van Dijk C., Brown V.K., Leps J., Rodriguez-Barrueco C., Roy J., Len T.A.D., Gormsen D., Korthals G.W., Lavorel S., Regina I.S., Smilauer P. 2000. Plant species diversity as a driver of early succession in abandoned fields: a multi-site approach. Oecologia, 124:91-99. 